\title{
Missense Mutation
}

National Cancer Institute

\section{Source}

National Cancer Institute. Missense Mutation. NCI Thesaurus. Code C18133.

A point mutation occurring within the protein-coding region of a gene, and which codes for a different amino acid than expected. 